\title{
Dynamics Finite Element for Ship Damage Collision Analysis
}

\author{
Hasanudin $^{1}$, Wasis D. Aryawan ${ }^{1}$, Achmad Zubaydi $^{1}$, and Teguh Putranto ${ }^{1}$
}

\begin{abstract}
Along with the growing fleet of vessels, ship collision accident cases are becoming more frequent. It is unavoidable that the rapid shipping due to the number of vessels that operate relatively large and the ship is waiting for the loading and unloading at the port. This study will examine the design of the solid bulk cargo ship safe for shipping operations congested areas. The finite element method is used to determine the amount of internal energy in the structure of damaged vessel. The striking ship is assumed a tanker that have a bulbous bow. Bulk carrier is designed with space of double skin $1.8 \mathrm{~m}$ and the structure of wing tank is determined previously. The results obtained from this research is the design of the cargo hold of bulk carrier that has a double skin to protect the leaking compartment when the ship was crashed. Penetration in depth $1.8 \mathrm{~m}$ will be occurred at ship if ship crashed is with speed 12 knots and weight 1400 tons.
\end{abstract}

Keywords-finite element, bulk carrier, double skin, penetration.

\section{INTRODUCTION}

One of the research about ship damage collision have carried out by Minorsky [1]. The absorbed damaged energy and kinetic energy are determined by using simple momentum theory. Interaction between ship and water around are assumed in constant added mass condition. Minorsky does also introduce the relation between deformed volume of structure and absorbed collision energy. This empirical method can be used for greater collision (in other word, for more $30 \mathrm{MJ}$ of absorbed energy). This approach is used generally dan modified by other researcher.

Probability damage stability of ship is depend on the subdivision of compartment that it have researched by Jasionowski. The more compartment built, the more time needed to load and unloading. Study of Formal Safety Assessment (FSA) of bulk carrier is also carried out by International Organization that is lead by Royal Institution of Naval Architects. The main goal of FSA is to investigate whatever the new requirement about survivability and structure fulfils the SOLAS Chapter XII [2].

There are 2 advantages bulk carrier that uses double skin: (i) ability to withstand influence collision causing more penetration than single skin and (ii) maintain the outer structure from corrosion caused by contact between steel of ship and load in cargo hold. Therefore, damaged of plate and profile can be avoided. The lightweight of double skin is more increase than single skin as shown at Figure 1.

\footnotetext{
${ }^{1}$ Hasanudin, Wasis D. Aryawan, Achmad Zubaydi, and Teguh Putranto are with Department of Naval Architecture and Shipbuilding Engineering, Sepuluh Nopember Institute of Technology, Surabaya, 60111, Indonesia. E-mail: hasanudin@na.its.ac.id; wasis@na.its.ac.id; zubaydi@gmail.com; theories@gmail.com.
}

One of the hull form design innovation is to change the ship structure that will definitely change the internal energy and the strength of ship. But, it needs to be also considered about the seakeeping and resistance if the innovation provide more advantages in ship design [2].

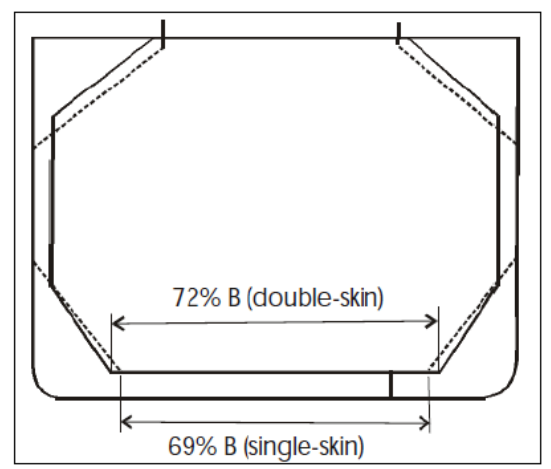

Figure 1. The midship section of double and single skin

Transient procedure during simulation process of ship collision could be carried out and give the sophisticated result. Theory, numerical, and experimental method are compared and analyzed in order to obtain the relation between the used methods [3]. The collision between ship and floating ice is analysed to obtain the internal energy occurs during the collision. Using simple formulation, the damage structure caused by collision can be researched [4].

Collision analysis with numerical simulation method of dynamic finite element so that the energy received by the vessel can be known [5]. The deeper penetration occurs, the more energy that can be absorbed. There was a time that happened was a constant force for the ship that crashed into the transverse construction of the ship that was hit so that the construction of this attempt to hold. The energy absorbed by the ship can be converted into the mass of the ship that rammed so it can be estimated that hit the ship size [6].

\section{METHOD}

This research uses numerical method which Finite Element Method (FEM) is chosen to solve the problem of dynamics analysis. Initially, two ships is modeled in one file or solution. Then, it is applied in boundary condition so that the collision phenomena are occurred.

\section{A. FEM Model of Two Ship}

Dynamic modelling for simulation of ship collision done until penetration of $1.8 \mathrm{~m}$. Modelling adapted to the model transverse to the ship was hit and models bulbous bow for ships crashing. Models made in one file so that the settings for the element type, material properties, etc. performed on the same file. Element types used in this model are good for Shell 163 ships crashing or the ship was hit. For the definition of material properties, plastic material kinematics applied to the ship was hit. It is 
intended to get the deformation and damage to the ship was hit.

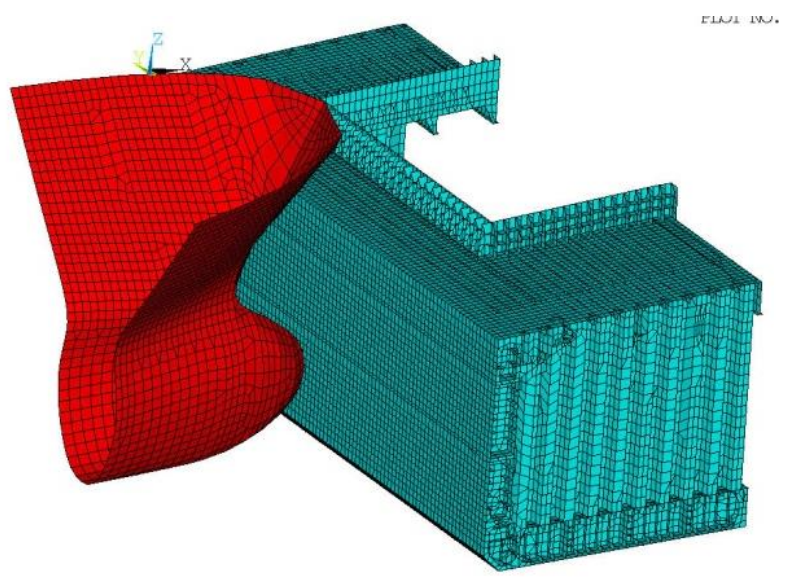

Figure 2. FEM model for two ships

\section{B. Material Properties}

Material used to model ship collision is mild steel that applied in whole of ship structure. But, for striking ship, the material properties is added for rigid body it means that the model does not appear the stress, energy, displacement, etc. Rigid body material was applied to the ship crashed. This is meant to avoid deformations and stresses on the ship that rammed that ship that rammed assumed completely rigid.

The most affect factor for analysis of FEM dynamics is the strain failure meaning that the parameter determines the failure of material.

TABLE 1.

MATERIAL PROPERTIES FOR STRIKING AND CRASHED SHIP

\begin{tabular}{|l|l|l|c|}
\hline No. & Input & Value & Dimension \\
\hline 1. & Density & 7550 & $\mathrm{~kg} / \mathrm{m}^{3}$ \\
\hline 2. & Elasticity Modulus & 220 & $\mathrm{GPa}$ \\
\hline 3. & Poisson Number & 0.33 & - \\
\hline 4. & Yield Stress & 320 & $\mathrm{MPa}$ \\
\hline 5. & Tangensial Modulus & 630 & $\mathrm{MPa}$ \\
\hline 6. & Hardness Parameter & 0 & - \\
\hline 7. & Strain Rate (C) & 3200 & $1 / \mathrm{s}$ \\
\hline 8. & Strain Rate (P) & 5 & - \\
\hline 9. & Strain Failure & 0.325 & - \\
\hline
\end{tabular}

\section{Boundary Condition}

The boundary conditions given to the ship was hit by a breakdown as follows:

- Fixed support, applied to corrugated bulkhead locations.

- Symmetrical boundary condition, applied to the location of the center line. It is intended to reduce the time computer solutions.

\section{Mass of Striking Ship}

Using simple physics law about the law of conservation energy, the conversion for internal energy can be used to obtain the mass of striking ship. It is based on the assumption that the energy had by ship structure can stop the ship moving or crashed ship.

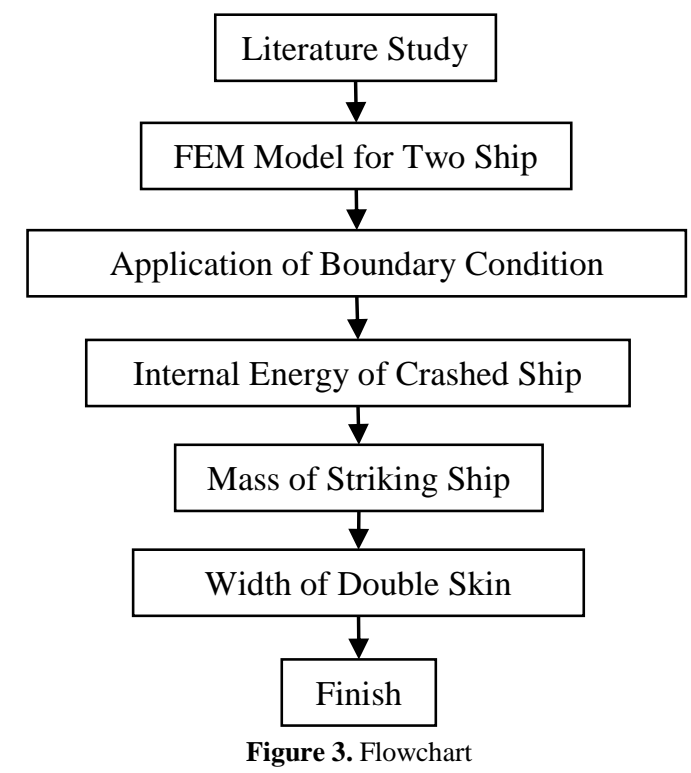

\section{RESULTS AND DiscUSSION}

Once the modelling is complete, then both models set the distance is so close together. The tip of the bulbous bow rammed the ship must be aligned with the plate side of the boat that was hit. The initial position of the collision should be right in the middle of the cargo hold and the higher the position set baseline collision ships rammed the boat parallel to the baseline hit.

\section{A. Force and Internal Energy During Collision}

Figure 3 shows a dynamic simulation of the collision vessel at $1657 \mathrm{~mm}$ penetration. If seen ships crashing, no deformation and stress on the hull of the crash. This is because the ship that rammed assumed as a rigid body while the ship was hit by a plastic material kinematics conditioned as meaning that the material will undergo elastic and plastic regions dependent on displacement occurs. The time needed to complete the simulation is 3 days with the CPU capacity Inter Core i5 RAM 16 GB.

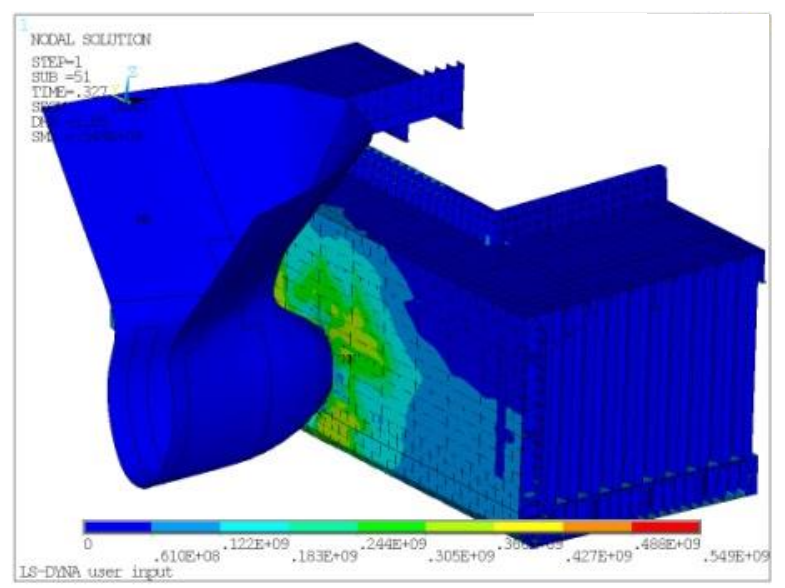

Figure 3. Distribution of stress at the crashed ship

From Fig. 4 can be seen the relationship between force against penetration. When a ship strikes a moment outside the ship hull plates, the speed at the time was 12 knots. 
Settings on the dynamic simulation are assumed constant speed when the ship hit until the specified penetration. Style and energy began to arise when the outer hull plates mashing vessel. Based on the formula Minorsky, the energy value is influenced by the slab thickness, length of penetration, penetration width, depth of penetration.

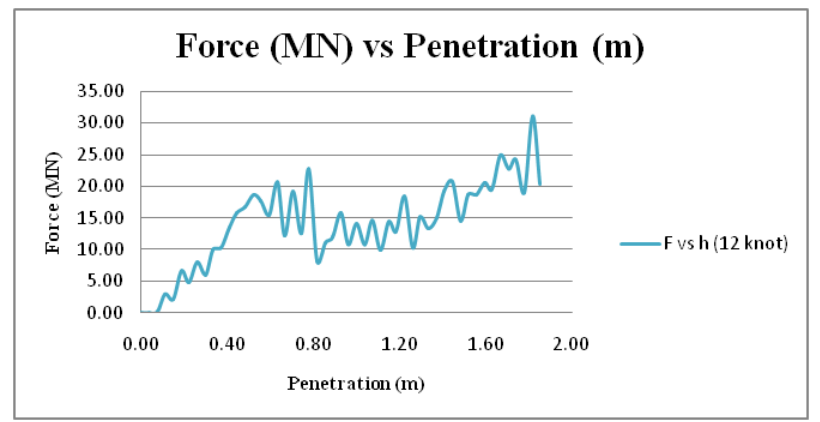

Figure 4. The graph of force and penetration in speed 12 knots

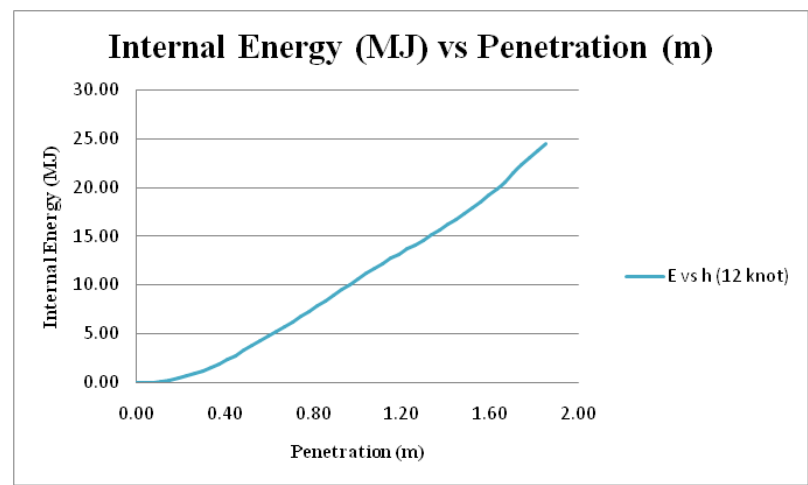

Figure 5. The graph of internal energy and penetration in speed 12 knots

Graph force versus penetration tends to increase with increasing penetration caused by contact that occurs between the bulbous bow with a ship that was hit is also getting bigger. Therefore, the frictional force and the contact force between the two create value in Fig. 4 is likely to increase. Fig. 4 shows the graph up and down behavior that can be interpreted that the condition construction damaged by being hit by a bulbous bow. From Fig. 5 can be seen the relationship between internal energy against penetration. When a ship strikes a moment outside the ship hull plates, the speed at the time was 12 knots. Settings on the dynamic simulation are assumed constant speed when the ship hit until the specified penetration. Style and energy began to arise when the outer hull plates mashing vessel. Based on the formula Minorsky, the energy value is influenced by the slab thickness, length of penetration, penetration width, depth of penetration. Graph internal energy versus penetration tends to increase with increasing penetration caused by contact that occurs between the bulbous bow with a ship that was hit is also getting bigger. Therefore, the frictional force and the contact force between the two create value in Fig. 5 is likely to increase. Fig. 5 shows the graph up and down behavior that can be interpreted that the condition construction damaged by being hit by a bulbous bow.

\section{B. Mass of Striking Ship}

Based on the results of the energy and the force generated by the simulation of ship collision can then be determined based on the width of the double skin aspects of ship collision. The energy is converted to mass ship rammed. The width of the double skin should have as effectively as possible so as not to detract too much load space. In addition, the probabilistic damage stability can also be improved from the previous width of the double skin. Selection of wide double skin in this study is based on aspects of ship collision damage. Therefore, the width of the double skin, the ship will be smaller due to possible damage to the hull in a ship collision.

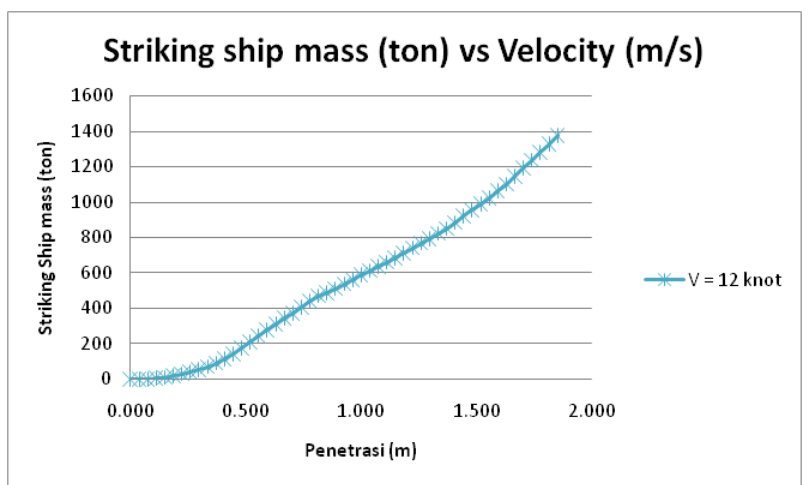

Figure 6. The graph of striking ship and velocity in speed 12 knots

Figure 6 shows the mass of the ship that rammed against the penetration produced with speed variation. From Fig. 6 it can be seen that the greatest gradient of the line contained in a line speed of 12 knots. From the results can be analyzed that the mass of the ship that crashed influenced by the ship speed crashed. The greater of ship mass, the deeper of the penetration. The mass of striking ship consists of deadweight and lightweight or relevant with ship displacement.

Such behaviour is influenced by the law of conservation of energy and momentum eternity law. In addition, the material properties also affect the ship was hit by internal energy. Speed mashing a material other material will cause a different style although the speed variation does not significantly affect the results of the internal energy occurs.

\section{CONCLUSION}

Based on the result and discussion, the conclusion taken at this research as follows:

1. The force and energy would being increase when the penetration is deeper. The pattern of force is increase and decrease along penetration which it means that the structure of double skin is damaged caused by the collision of striking ship.

2. Mass of striking ship is 1400 ton would cause the damage of inner hull when the striking ship moves speed 12 knots.

\section{ACKNOWLEDGEMENTS}

Researcher would like to express the appreciation for LPPM ITS that have given the fund and support through Penelitian Pemula Grant in 2016.

\section{REFERENCES}

[1] A. Jasionowski, D. Vassalos., "Ship Vulnerability to Flooding", Safety At Sea Ltd., The Ship Stability Research Center, University of Glasgow Strathclyde, UK, 2009.

[2] T. Putranto and A. Sulisetyono, "Analisa Numerik Gerakan dan Kekuatan Kapal Akibat Beban Slamming Pada Kapal Perang 
The $2^{\text {nd }}$ International Seminar on Science and Technology

August $2^{\text {nd }}$ 2016, Postgraduate Program Institut Teknologi Sepuluh Nopember, Surabaya, Indonesia

Tipe Corvette", Jurnal Ilmu Pengetahuan dan Teknologi Kelautan, Vol. 12, No. 3, Universitas Diponegoro, 2015.

[3] M. J. Petersen, "Dynamics of Ship Collision", Ocean Engineering Journal, Vol. 12 (VII), pp. 111-123, 1982.

[4] O. Ozguc, Das. P. K., Baltrop, N., "A Comparative Study on the Structural Integrity of Single and Double Side Skin Bulk Carrier Under Collision Damage", Department of Naval Architecture and Marine Engineering, University of Glasgow and Stratchlyde, UK, 2006.

[5] MARPOL, "Regulation 18 - Segregrated Ballast Tanks", 2002.

[6] T. Putranto, W. D. Aryawan, A. Zubaydi, "Kajian Penentuan Lebar Double Skin Bulk Carrier Ditinjau Dari Damage Collision", Seminar Nasional Pascasarjana, ITS, 2013. 